\title{
The Organisational Culture Types of South African Firms
}

\section{F W Struwig and E E Smith}

Department of Business Management, Vista University, Port Elizabeth

\begin{abstract}
This article sets out to examine the organisational culture types of South African firms. A literature study revealed four common organisational culture types, namely a power, role, task and person culture. An empirical study of 3000 South African firms by means of a self-administered questionnaire, investigated which of the four organisational culture types the firms exhibit. It appears that most of the respondent firms have a task culture. This culture is one that can adapt quickly, and where influence is based on expertise rather than personal authority. This in turn indicates that most South African firms do have an organisational culture that is compatible with a changing and competitive environment.
\end{abstract}

JEL M14

\section{INTRODUCTION}

Fischer (1992: 2) maintains that an understanding of the organisational culture of a firm is important to ensure its success in a rapidly changing environment. Lankford and Mintu-Wimsatt (1999) conclude that the organisational culture has a significant impact on a firm's long-term economic performance and productivity, that determine the success or failure of firms.

Although Schneider (1990: 21) has stated that the organisational culture concept is relatively young on which few reviews and critiques have been written, Weeks (1988: 69) maintains that managers are increasingly realising the importance of organisational culture. Yet, managers often tend to have only a vague knowledge of the concept itself. Martins (1993: 1) agrees that despite the increasing awareness and importance of organisational culture, there is confusion on what exactly it means. Silvester and Anderson (1999) also indicate that it is often difficult to define organisational culture precisely, as it includes various concepts. 
This article sets out to examine the organisational culture types of South African firms. The first aspect to be highlighted is to define the concept organisational culture and to discuss its importance. Then a brief exposition of the research methodology follows. Last, the most important results of our particular survey and their managerial implications are discussed.

\section{A THEORETICAI OVERVIEW OF ORGANISATIONAI CULTURE}

\subsection{Defining organisational culture}

Defining the concept "organisational culture" is a difficult task, one that many writers avoid, assuming that the reader understands the concept (Weeks, 1988: 42). Williams, Dobson and Walters (1990: 9) indicate that most people agree that organisational culture exists, but few agree on what it is. Various definitions have been given of the concept organisational culture in the context of anthropology, organisational psychology and management theory. By 1952, one hundred and sixty-four definitions of organisational culture had already been identified (Fischer, 1992: 2). From the literature (see for example Fey \& Claes 1999: 9; Johnson 1992: 31; Montanari, Morgan \& Bracker, 1990: 230 and Schein, 1990: 111) emerges that organisational culture includes the dominant beliefs, values and norms of the members of the group that forms the organisation. From a business perspective, organisational culture will therefore include the dominant values, beliefs and norms of the members (both employees and employers) of a firm.

\subsection{Importance of organisational culture}

Montanari et al. (1990: 233) assert that a strategy is most likely to succeed when there is cultural alignment. South African researchers (see e.g. De Klerk, 1989 and Weeks, 1988) contend that organisational culture should be part of the strategic management process. Organisational culture is therefore important to any firm that wants to implement strategic management successfully. Montanari et al. (1990: 232) further point out that strong organisational cultures have been cited as a reason for continued excellence, superior financial performance and the ability tc adapt and innovate. Schein (1986: 84) gives various reasons why organisational culture plays an important role in a firm. The failure of mergers, acquisitions and diversifications may be ascribed to a "cultural mismatch" (Maron \& van Bremen, 1999). Failure to integrate new technologies in a firm can be seen as a culture change problem.

If groups in a firm get into conflict with each other, reducing the conflict is often difficult, because a group needs to maintain its identity and one of the best ways 
of doing so is to compare and contrast it with other groups. The conflict helps to build and maintain intragroup culture. Ineffective meetings and communication breakdowns can be productively analysed from a cultural perspective. The organisational culture also plays an important role in the socialisation process of "fitting people into a structure". Productivity is a cultural phenomenon at a given work group level and at the level of the total organisation too.

Organisational culture also leads to consensus on the core mission, primary tasks and latent functions of the firm. The organisational culture of a particular firm will have a critical influence when determining the mission of a firm, its raison d'être. Consensus on remedial and repair strategies also influences the culture of a firm. Responses to crises provide opportunities for culture building and reveal aspects of the culture that have already been built. Organisational culture indicates group boundaries and criteria for inclusion. Consensus on criteria for membership is always a means of determining whether a culture unit exists in any group. Specific rewards and punishments, and the way in which these are administered, constitute one of the most important cultural characteristics of a firm.

Robbins (1992: 256) points out that organisational culture performs a number of functions within a firm. Firstly, it has a boundary defining role by creating distinctions between firms. Secondly, it conveys a means of identity to the members of the firm. Thirdly, organisational culture facilitates the generation of commitment to something larger than one's individual self-interest. Fourthly, it leads to stability of a social system and organisational culture is the glue that holds a firm together. Finally, organisational culture serves as a sense-making and control mechanism which guides and shapes the attitudes and behaviour of group members.

\subsection{Characteristics of organisational culture}

Thompson and Strickland (1992: 253) maintain that every firm has a unique organisational culture. An organisation's culture can be weak and fragmented in the sense that most members do not have a deeply felt sense of the firm. On the other hand, a firm's organisational culture can be strong and cohesive when most people in the firm understand and relate to its objectives and strategy. Although Handy (1985: 196) agrees that organisational culture cannot be defined precisely, for it is something perceived and felt, it should however be clear that organisational culture reveals certain properties that make it possible to identify or characterise the organisational culture of a firm. Handy's view (1985: 196) is shared by Trice and Beyer (1993: 5) who have described organisational culture as something symbolic, emotional, pervasive and vague. Organisational culture is not something clearly perceptible but difficult to characterise or identify. 
Hampden-Tumer (1990: 12), in turn, characterises organisational culture in terms of the advantages or value that it has for the individual or group member. Characteristics such as rewards for excellence, a set of affirmations, provisions of continuity and identity and a state of balance between reciprocal values, emphasise the meaning of organisational culture to an individual or group member. The characteristics proffered by Rue and Holland (1986: 440), such as individual autonomy, identification and performance reward, closely correlate with the Hampden-Turner characteristics (1990:12) as an indication of the value thereof to a group member. Fischer (1992: 6) however emphasises the general characteristics of organisational culture, in terms of the role that it plays in a firm to satisfy the specific needs of a firm.

\subsection{Types of organisational culture}

Although Fombrum (1983: 139) asserts that the culture of each firm is unique in scope and content, some researchers (see e.g. Deshpande \& Parasuraman, 1986; Kono, 1990; Rue \& Holland, 1986 and Silvester \& Anderson, 1999) divide organisational cultures into various types. Figure 1 shows the organisational culture types identified by various authors.

In analysing the organisational culture types in Figure 1, it is possible to identify four major classifications of these types. Figure 2 shows the classification of organisational culture types. 


\section{Figure 1 Types of Organisational Culture}

\begin{tabular}{|l|l|l|}
\hline According to Handy & $\begin{array}{l}\text { According to Deal } \\
\text { and Kennedy }\end{array}$ \\
\hline - Power & $\begin{array}{l}\text { Tough Guy/Macho } \\
\text { - Role } \\
\text { - Task }\end{array}$ \\
- Person & Work hard/Play \\
- Bet your company \\
- Process Culture \\
\hline
\end{tabular}

\begin{tabular}{|c|c|c|c|}
\hline & \multicolumn{2}{|c|}{ According to Trice and Beyer } & \\
\hline & $\begin{array}{l}\text { Type A } \\
\text { Type Z } \\
\text { - Caring } \\
\text { - Exacting } \\
\text { - Paranoid } \\
\end{array}$ & $\begin{array}{l}\text { - Type J } \\
\text { - Apathetic } \\
\text { - Charismatic } \\
\text { - Integrative } \\
\text { - Avoidant } \\
\end{array}$ & \\
\hline & \multicolumn{2}{|c|}{$\begin{array}{l}\text { Bureaucratic } \\
\text { - Sensation-thinking } \\
\text { - Intuition-thinking } \\
\text { - } \text { Intuition-feeling } \\
\end{array}$} & \\
\hline According to Kono & & & $\begin{array}{l}\text { According to } \\
\text { Hampden-Turner }\end{array}$ \\
\hline $\begin{array}{l}\text { Vitalised } \\
\text { - Follow the leader } \\
\text { - Bureaucratic } \\
\text { - Stagnant and follow } \\
\text { the leader }\end{array}$ & & & $\begin{array}{l}\text { - Need to adapt } \\
\text { - Need to integrate } \\
\text { - Need for change } \\
\text { - Need for key } \\
\text { continuities }\end{array}$ \\
\hline
\end{tabular}

Figure 2 Classification of Organisational Culture Types

\begin{tabular}{|l|l|l|l|l|}
\hline Author & Type 1 & Type 2 & Type 3 & Type 4 \\
\hline Handy & Power & Role & Task & Person \\
\hline Trice \& Beyer & Type A & Type A & Type J & Type Z \\
& $\begin{array}{l}\text { Sensation- } \\
\text { Thinking }\end{array}$ & $\begin{array}{l}\text { Sensation- } \\
\text { thinking }\end{array}$ & $\begin{array}{l}\text { Intuition- } \\
\text { thinking }\end{array}$ & $\begin{array}{l}\text { Intuition- } \\
\text { feeling }\end{array}$ \\
& $\begin{array}{l}\text { Apathetic } \\
\text { Paranoid }\end{array}$ & $\begin{array}{l}\text { Apathetic } \\
\text { Bureaucratic }\end{array}$ & $\begin{array}{l}\text { Exacting } \\
\text { Avoidant }\end{array}$ & $\begin{array}{l}\text { Caring } \\
\text { Charismatic }\end{array}$ \\
\hline
\end{tabular}


Figure 2 continued

\begin{tabular}{|l|l|l|l|l|}
\hline Author & Type 1 & Type 2 & Type 3 & Type 4 \\
\hline Handy & Power & Role & Task & Person \\
\hline Kono & $\begin{array}{l}\text { Stagnant and } \\
\text { follow the } \\
\text { leader }\end{array}$ & $\begin{array}{l}\text { Bureaucratic } \\
\text { Stagnant }\end{array}$ & $\begin{array}{l}\text { Follow the } \\
\text { leader and } \\
\text { vitalised }\end{array}$ & Vitalised \\
\hline $\begin{array}{l}\text { Deal \& } \\
\text { Kennedy }\end{array}$ & $\begin{array}{l}\text { Tough guy/ } \\
\text { Macho }\end{array}$ & $\begin{array}{l}\text { Bet your } \\
\text { company }\end{array}$ & $\begin{array}{l}\text { Work hard/ } \\
\text { play hard }\end{array}$ & Process \\
\hline $\begin{array}{l}\text { Hampden- } \\
\text { Turner }\end{array}$ & $\begin{array}{l}\text { Need for key } \\
\text { continuities }\end{array}$ & $\begin{array}{l}\text { Need for } \\
\text { periodic } \\
\text { change }\end{array}$ & $\begin{array}{l}\text { Need for } \\
\text { change }\end{array}$ & $\begin{array}{l}\text { Need to } \\
\text { integrate }\end{array}$ \\
\hline
\end{tabular}

Considering this classification scheme, the four organisational types discussed by Handy (which correspond to the classifications of the other authors) are used for the purpose of this study. This typology of organisational culture assists in understanding the ideological conflicts that arise within firms. Deep-seated beliefs exist about the way that work should be done. This fourfold classification is next discussed.

\section{- Power culture}

This culture depends on a central power source, with rays of power and influence spreading out from a central figure. There are few rules and procedures in this type of culture - control is exercised largely by the central figures. The power culture, sometimes also called the club culture (Thompson, 1990: 74), is a proud and strong culture. Another characteristic of power cultures is that much faith is put in the individual and little in committees or teamwork.

\section{- Role culture}

The role culture is often stereotyped as bureaucracy. Organisational culture is built around defined jobs, rules and procedures. This culture operates according to logic and rationality and its strength lies in its functions or specialists. Top management is characterised by a small span of management. The firm tends to operate within a stable external environment where creative or innovative behaviour is discouraged as a rule. This culture type is slow to perceive the need for change and slow to change even if the need is seen. Role cultures offer security and predictability to the individual. Employees who are orderly, punctual and detail orientated are well suited to a role-cultural environment. 


\section{- Task culture}

The task culture is job or project-orientated and extremely adaptable. For a particular problem situation people and other resources can be drawn from various parts of the firm on a temporary basis. The matrix organisation is one structural form of the task culture. Influence within the firm is based on expertise rather than personal authority.

\section{- Person culture}

The individual is the central point in the person culture. The firm exists to help the individual rather than the other way round. Groups of professional people, such as doctors, dentists and architects are examples of a person culture. This fourfold classification of organisational culture types is used in the empirical survey to investigate the organisational culture types of South African firms. This is in line with the dimensions determined by the cross cultural research of Hostede (1980).

\section{RESEARCH METHODOLOGY}

For this study, the target population was chosen from South African firms. Private and public companies and close corporations employing more than 100 employees were included in the population. The sample was drawn randomly by Matrix Marketing. Clear instructions were given on how the sample should be drawn. For this study it was decided to include firms from the following categories/activities in the sample frame: manufacturing, electricity, construction, trade, transport and other activities not listed. Due to factors such as cost, time and low response rates, a sample of 3000 firms was chosen and it was decided not to do a follow-up study. A proportional stratified random sample was drawn. Table 1 shows the forms of enterprise included in the sample and those of the respondents.

Table 1 Forms of Enterprise of Sample and Respondents

\begin{tabular}{|l|c|c|c|}
\hline \multicolumn{1}{|c|}{$\begin{array}{c}\text { Forms of } \\
\text { Enterprise }\end{array}$} & $\begin{array}{c}\text { Number of } \\
\text { Firms in Sample }\end{array}$ & $\begin{array}{c}\text { \% Of total } \\
\text { Sample Firms }\end{array}$ & $\begin{array}{c}\text { \% Return } \\
\text { Respondents }\end{array}$ \\
\hline Public Companies & 490 & 16 & 4 \\
\hline $\begin{array}{l}\text { Private } \\
\text { Companies }\end{array}$ & 2212 & 74 & 27 \\
\hline $\begin{array}{l}\text { Close } \\
\text { Corporations }\end{array}$ & 298 & 10 & 63 \\
\hline \multicolumn{1}{|c|}{ TOTAL } & 3000 & 100 & 94 \\
\hline
\end{tabular}


From Table 1 it can be seen that the majority of the respondent firms were close corporations, although close corporations were not the majority in the sampling frame. Section A of the questionnaire, which investigates the organisational culture types of South African firms, consisted of 15 closed-ended questions with forced ranking options. Respondents were asked to rank four options, reflecting the four culture types, in order of importance/preference. A nominal scale was used for Section B of the questionnaire (biographical data of the respondents). Once a questionnaire was received from a respondent, it was inspected to determine its acceptability. A total of 188 usable questionnaires was received and included in the analysis of the data (effective response rate of $6.27 \%$ ).

\section{SURVEY RESULTS}

\subsection{Descriptive statistics}

To analyse the results of the responses investigating the culture types of South African firms, the following procedure was used. There were 15 aspects that each contained four statements, reflecting the four cultural types: power culture (first statement); role culture (second statement); task culture (third statement) and person culture (fourth statement). The sum value of each statement reflects the overall ranking of the statement. Individual statements were then ranked. Statements with the lowest sum value are regarded as the most important (ranked first). Table 2 indicates the total sum value and therefore the manifestation of organisational culture types of South African organisations.

Table 2 A Summary of Results on Manifestation of Different Organisational Culture Types

\begin{tabular}{|c|c|c|c|}
\hline Overall ranking & Culture type & Total sum value & $\begin{array}{c}\text { Number of } \\
\text { statement }\end{array}$ \\
\hline 1 & Task & 4931 & 3 \\
\hline 2 & Role & 6597 & 2 \\
\hline 3 & Power & 7755 & 1 \\
\hline 4 & Person & 8217 & 4 \\
\hline
\end{tabular}

The survey results in Table 2 show that the task culture appears to be the most dominant culture type and was therefore ranked overall first (lowest sum value). The role culture was ranked overall by respondents as the second most dominant culture type in South African firms. 
The frequency distribution of the results in Section B of the questionnaire (classification data) indicates that the (admittedly slender) majority of the respondents $(51 \%)$ were employed in firms whose main activity is manufacturing. The majority of the respondents $(63 \%)$ were employed in firms that are private companies and had, on average, a workforce that varied between 100 and 199 employees. Seventy-nine per cent of participative firms had an annual gross revenue of more than R10 million. Just more than half $(51 \%)$ of participative firms described their environment as characterised by moderate changes/innovation. Sixty-three per cent of the respondents who completed the questionnaires can be classified as part of top management.

Table 3 highlights the descriptive statistics in Section $\mathrm{A}$ of the questionnaire (organisational culture).

Table 3 A Summary of the Descriptive Statistics for the Different Organisational Culture Types

\begin{tabular}{|l|c|c|c|c|}
\hline \multicolumn{1}{|c|}{ Statistic } & $\begin{array}{c}\text { Power } \\
\text { culture }\end{array}$ & Role culture & Task culture & $\begin{array}{c}\text { Person } \\
\text { culture }\end{array}$ \\
\hline Mean & 2,750 & 2,339 & 1,749 & 2,914 \\
\hline Mode & 3,200 & 2,333 & 1,533 & 2,867 \\
\hline Median & 2,867 & 2,333 & 1,667 & 2,867 \\
\hline $\begin{array}{l}\text { Standard } \\
\text { deviation }\end{array}$ & 0,613 & 0,361 & 0,432 & 0,432 \\
\hline Standard error & 0,045 & 0,026 & 0,032 & 0,032 \\
\hline
\end{tabular}

Analysing the mean scores for the four culture types, it appears to correlate with the overall ranking order (preference) of the culture types. The standard deviation scores are low which shows that there are low variances in dispersion of scores.

\subsection{The relationship between the different variables}

The MANOVA procedure, which uses Wilks's lambda multivariate test of significance, was used to investigate whether differences occur among the variables. The univariate analysis of variance using the univariate F-test, was used to determine where the differences occur. In these tests the independent variables were the biographical data of the respondents, and the dependent variables were the questions relating to organisational culture types. The 60 variables in Section $A$ of the questionnaire are ordinal data variables, using a forced-ranking scale. The variables in Section B of the questionnaire are on a nominal scale. The results of the MANOVA procedures to investigate the differences between 
variables are given in Table 4.

Table 4 The Results of the MANOVA Procedure to Investigate the Relationships Between the Variables

\begin{tabular}{|l|l|c|c|}
\hline \multicolumn{1}{|c|}{$\begin{array}{c}\text { Independent } \\
\text { variable }\end{array}$} & \multicolumn{1}{|c|}{$\begin{array}{c}\text { Dependent } \\
\text { variable }\end{array}$} & $\begin{array}{c}\text { Wilks's Lambda } \\
\text { F-test of } \\
\text { significance P- } \\
\text { value }\end{array}$ & $\begin{array}{c}\text { Univariate F-test } \\
\text { of significance } \\
\text { P-Value }\end{array}$ \\
\hline $\begin{array}{l}\text { Main activity of } \\
\text { the firm }\end{array}$ & All culture types & 0,721 & - \\
\hline $\begin{array}{l}\text { Forms of } \\
\text { enterprise }\end{array}$ & All culture types & 0,110 & - \\
\hline Workforce size & All culture types & 0,141 & - \\
\hline $\begin{array}{l}\text { Annual gross } \\
\text { revenue }\end{array}$ & All culture types & 0,007 & $\begin{array}{l}\text { Power }=0,010^{*} \\
\text { Role }=0,192 \\
\text { Task }=0,001^{* *} \\
\text { Person }=0,911\end{array}$ \\
\hline $\begin{array}{l}\text { Type of the } \\
\text { Environment } \\
\text { of the Firm }\end{array}$ & All culture types & 0,013 & $\begin{array}{l}\text { Power }=0,040^{*} \\
\text { Role }=0,116 \\
\text { Task }=0,079 \\
\text { Person }=0,201\end{array}$ \\
\hline
\end{tabular}

* Significance level of 0,05

** Significance level of 0,01

From Table 4, it can be concluded that manufacturing firms do not differ significantly from firms with other main activities, regarding the type of organisational culture. The P-value of 0,721 of the Wilks's lambda F-test of significance indicates that there is no relationship between the main activity of a firm and its organisational culture. There is no significant relationship (Wilks's lambda $P=0,110$ ) between the forms of enterprise and the organisational culture type. Firms with different forms of enterprise are not significantly different with regard to the type of organisational culture exhibited. The survey results also indicated that there is no significant relationship (Wilks's lambda $P>$ 0,05 ) between the workforce size of a firm and its organisational culture type. There is a highly significant relationship between the annual turnover and the organisational culture type of a firm. The univariate F-test of significance, indicates a significant difference for power culture $(\mathrm{P}$ value $<0,05)$ and also a highly significant difference for task culture (P value $<0,01)$. According to Wilks's lambda F-test of significance, there is also a significant relationship ( $P$ value $<0,05$ ) between the type of environment in which a firm operates and the 
organisational culture type. In analysing the results of the univariate F-test of significance, it appears that only the power culture shows a significant relationship $(P$ value $<0,05)$ with the environment in which the firm operates.

\section{CONCLUSION}

Having a clear understanding of the organisational culture concept is important for managers today, as management needs to understand the basic process involved in the formation and preservation of organisational culture. Although every firm has its own unique culture, certain common characteristics of organisational culture were identified in our research. When a broad approach to the concept of organisational culture is taken, the real importance of organisational culture is often underestimated. The organisational culture in a firm plays an important role in its daily administration and performance. To assess the culture of a firm is no easy task.

Our empirical results show that a task culture was the most dominant type of organisational culture implemented by the respondents, that is, a task culture was ranked first overall. Of all the surveyed firms, it appears that a person culture is the least dominant type of culture, and it was ranked last. Managers should understand the nature and characteristics of their respective organisational cultures. The most important characteristics of a task culture are the following:

- Job or task orientated

- Extremely adaptable/flexible

- Team culture

- Whole emphasis is on getting the job done

- Works quickly (each group has decision-making power)

- Appraisal by result

- Operates in competitive markets

- Integration, sensitivity and creativity more important than depth of specialisation

- Individual freedom

- The end product is all-important

From the above, it can be seen that a task organisational culture is flexible and can adapt to changes. It therefore seems that the South African firms, in general, do have organisational cultures that are conducive to change management, and that they can probably compete internationally. Statistical analysis was used to describe the relationships between the type of 
organisational culture and other characteristics of the firm. The results indicate that the main activity of a firm seems to play no role in determining its type of organisational culture. Management should note that the form of enterprise (whether private or public company or close corporation) bears no direct relationship to the organisational culture of that firm. As there is no clear relationship between the workforce size of a firm and organisational culture type, the number of people employed by a firm will therefore not determine its culture type.

It is however important to note that there is a highly significant relationship between the annual gross revenue of a firm and its organisational culture type. The organisational cultures of those firms that have power and task cultures in particular, tend to show a significant relationship with the annual gross revenue. If the firm exhibits a power or task culture, it may be inferred that the anmual gross revenue of the firm will play a role in the determination of those cultures (power and task). After analysis and identification of a firm that has a power culture, management should realise that the environment plays an important role in the determination of a power culture.

The present study has certain shortcomings that need to be kept in mind. Thus, the low response rate is a limitation. Although various measures were taken to seek a higher response rate, the result was still unsatisfactory. The number of usable questionnaires was however satisfactory for statistical analysis and to draw useful conclusions. This study was restricted to the manufacturing sector of the economy, and a similar study including the primary and service sectors is proposed. Other areas for future research include the influence of trade unions in shaping the culture of organisations, culture diversity in the workplace and its effect on organisational culture, and the influence of a firm's organisational culture on the implementation of affirmative action.

\section{REFERENCES}

1 DE KLERK, A. (1989) 'n Ondersoek na Aspekte van Korporatiewe Kultuur by ESKOM, Unpublished M.Comm Thesis, University of South Africa, Pretoria.

2 DESHPANDE, R. and PARASURAMAN, A. (1986) "Linking Corporate Culture to Strategic Planning", Business Horizons, 29, May-June: 28-37.

3 FEY, C.F. and CLAES, N. (1999) "Organisational Cultures in Russia: The Secret of Success", Business Horizons, 42(6): 47-56.

4 FISCHER, E. (1992) "Organisasiekultuur as Fokuspunt in die Bepaling van Bestuursprioriteite en Hantering van Eietydse Vraagstukke", Paper 
delivered at 4th Annual Conference of The South African Institute for Business Scientists, Bloemfontein: 22 June 1992.

5 FOMBRUM, C.J. (1983) "Corporate Culture, Environment, and Strategy", Human Resource Management, 22(1): 138-52.

6 HANDY, C.B. (1985) Understanding Organizations, Penguin Books Ltd., England.

7 HAMPDEN-TURNER, C. (1990) Corporate Culture, Hutchinson, London.

8 HOFSTEDE, G. (1980) Culture's Consequences, Sage, Newbury Park, CA.

9 JOHNSON, G. (1992) "Managing Strategic Change - Strategy, Culture and Action", Long Range Planning, 25(1): 28-37.

10 KONO, T. (1990) "Corporate Culture and Long-range Planning", Long Range Planning, 23(4): 9-19.

11 LANKFORD, W and MINTU-WIMSATT, A. (1999) "Define America's Organisational Culture." Women in Management Review, 14(6): 5-7.

12 MARON, R.M. and VAN BREMEN, L. (1999) "The Influence of Organisational Culture on Strategic Alliances," Association Management, 51(4): 86-92.

13 MARTINS, N. (1993) "Die Waarde van Organisasiediagnose vir die SuidAfrikaanse Onderneming", Paper delivered at EBM Research Conference. Bloemfontein: 29-30 November 1993.

14 MONTANARI, J.R., MORGAN, C.P. and BRACKER, J.S. (1990) Strategic Management - A Choice Approach, The Dryden Press, Chicago.

15 ROBBINS, S.P. (1992) Essentials of Organisational Behaviour, PrenticeHall, Inc., New Jersey.

16 RUE, L.W. and HOLLAND, P.G. (1986) Strategic Management, McGraw-Hill, Inc., New York.

17 SCHEIN, E.H. (1986) "Are You Corporate Cultured?", Personnel Journal, November: 83-96.

18 SCHEIN, E.H. (1990) Organisational Culture, (2 ${ }^{\text {nd }}$ ed.) Jossey-Bass Publishers, San Francisco.

19 SCHNEIDER, B. (1990) Organisational Culture and Climate, JosseyBass Publishers, San Francisco.

20 SILVESTER, J. and ANDERSON, N.R. (1999) "Organisational Culture Change: An Intergroup Attributional Analysis", Journal of Occupational \& Organisational Psychology, 72(1): 1-24.

21 THOMPSON, J.L. (1990) Strategic Management, Chapman \& Hall, London.

22 THOMPSON, A.A. and STRICKLAND, A.J. (1992) Strategy Formulation and Implementation: Tasks of the General Manager, Richard D. Irwin, Inc., Boston. 
23 TRICE, H.M. \& BEYER, J.M. (1993) Cultures of Work Organizations, Prentice-Hall, Inc., New Jersey.

24 WEEKS, R.V. (1988) The Interactive Role of Organizational Strategy and Culture: A Strategic Management Approach, Unpublished M.Com Thesis, RAU, Johannesburg.

25 WILLIAMS, A., DOBSON, P. and WALTERS, M. (1990) Changing Culture: New Organizational Approaches, London: Institute of Personnel Management, London. 